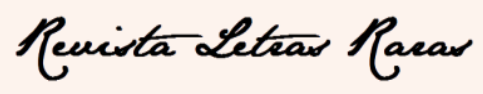

ISSN: $2317-2347$ - v. 7, n. 3 (2018)

\title{
Professor bom é professor morto
}

Leandro Marlon Barbosa Assis*

Você não leu errado, caro(a) leitor(a). Menos errado, ainda, caso tenha atribuído a frase a algum candidato da última disputa pela presidência da República. A associação direta é clara e não permite rodeios: professor bom é professor morto. Mais claro do que a afirmação direta e fatal é a de que a profissão docente agoniza na contemporaneidade. Deixe-me explicar nas linhas seguintes e, assim, poderemos alcançar o mesmo estágio de síntese angustiante.

Professor, enquanto educador, está em extinção. Temos, claro, subespécies adaptadas ao ambiente. Destaco duas: o professor de bico e o professor por frustração. O professor de bico, carinhosamente chamado de Pedro, pensa em exercer o magistério para ser um ganha-pão enquanto o negócio pensado e praticado por ele não vinga. $O$ empreendedor Pedro busca, então, nas salas de aula, a chance de se manter vivo enquanto seu negócio naufraga. Ele leciona Língua Portuguesa por amar as palavras na adolescência. Projetava, à época, lançar livros e, quando grisalho, vencer o prêmio Jabuti. Entre seus dezoito e dezenove anos, ouviu do pai, alcoólatra inveterado, a frase que o marcou duramente tal qual o gado selecionado para o abate: a poesia não te levará a lugar nenhum. Entre lágrimas de olhos que rolavam os últimos versos rimados, escutou o som sinfônico de sua mãe sendo espancada. A inércia de Pedro para ajudar sua progenitora e, também, seus sonhos, tornou aquele jovem aprendiz das letras em mero receptáculo de afazeres burocráticos no caixa do supermercado. Como já havia cursado um ano da faculdade de Letras, manteve o curso para ter um diploma de Ensino Superior, visando concursos em nome do pragmatismo. Durante os anos literários sem poesia, vendia doces e era bem recebido pelos colegas. Viu, ali, um novo hobby. Ao concluir a faculdade, buscou concursos diversos e a frustração da reprovação o levou às salas de aula. O bico, então, foi posto em prática em nome do empreendimento de doces. Suas quatro lojas abertas há dois meses foram fechadas pela crise política de um país que não lê e, por fim, seu carrinho de vendas foi rebocado ontem pela prefeitura

\footnotetext{
* Mestrando do Programa de Pós-Graduação em Mídia e Cotidiano da Universidade Federal Fluminense PPGMC/UFF e bolsista (2017-2018) da Coordenação de Aperfeiçoamento de Pessoal de Nível Superior CAPES, Brasil, leandro88marlon@ gmail.com.
} 


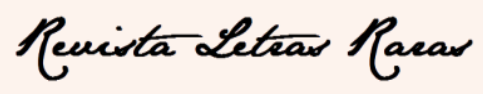

ISSN: $2317-2347$ - v. 7, n. 3 (2018)

pela falta de alvará. Diante de sua dor, culpou os estudantes por seu fracasso e reproduzia, neles, a frase de seu pai sem se importar no efeito devastador de sua incompreensão da docência.

Na mesma escola, como que por um acaso desejado para a crônica que leem, habita a professora por frustração. Diferente de Pedro, Bárbara exerce sua docência por não ter conseguido se tornar advogada. A jovem professora desejou, desde a adolescência, ser aquela que honraria sua família. Quando seus pais a perguntavam o que seria, logo davam as opções: médica, engenheira ou advogada? Como ela pensava nos números de contas complexas que faziam as matrizes escolares parecerem exercícios primários, encaminhou-se para o Direito. Pensava ela que, cursar cinco anos e gastar alguns milhares de reais da família bastaria. Contudo, apropriando-nos de Drummond, havia uma OAB pelo meio do caminho. Bárbara, portanto, terminou sua trajetória como bacharel sem poder advogar. Pensando na frustração que teve, tornou-se professora de Sociologia por ver a oportunidade de ter uma profissão de maneira simples e direta. Bárbara leciona há três anos todos os imprevistos da vida e insiste em dizer aos jovens que tudo depende deles. Ela, num irônico ato pedagógico, fala que tudo pode acontecer se eles realmente se esforçarem, pois, a vida não é para os medíocres. Ao ano, Bárbara consome algumas pílulas de medicamentos controlados para uma vida desgovernada. A sala de aula, então, é "barbarizada" pela sequência de incompreensões e profundidade que a disciplina pede. Tal qual Pedro, culpou os estudantes por seu fracasso e reproduzia, neles, um exame de ordem que os impedia de seguir, tornando-os seres sem sonhos.

O que as duas espécies não trazem no peito, infelizmente, é a criticidade do professor educador, raro nos dias de hoje. Tanto Pedro quanto Bárbara, não percebem que o que os limitava era, na verdade, desejos outros que os impediam de caminhar em busca da utopia galeana. Pararam diante de obstáculos e se limitaram a ser o que outros julgavam que eles poderiam ser. Foram menos e nunca conheceram o "ser mais" que Paulo Freire sempre escreveu em seus livros lidos pelos professores educadores. Pior: nunca compartilharam com os jovens educandos as possibilidades de romper um ciclo de mediocridade que se assegura na sua irmã gêmea que é a meritocracia. Contudo, os professores educadores seguem sendo abatidos por empresários gananciosos e gestores burocráticos: no lugar de balas, mesmo que defendidas por algumas pessoas, as 


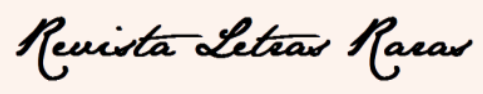

ISSN: $2317-2347$ - v. 7, n. 3 (2018)

estatísticas estrangulam o ensino-aprendizagem e adoecem os corpos docentes de modo mais eficiente. Caso duvide, pense em como Pedro corrói a essência docente dos seus colegas de trabalho com toda a sua frustração e, ainda, finca palavras pesadas demais para os corações joviais. A docência, enquanto prática do professor educador, encontra o limite pela conta bancária zerada pela falta de reajustes por parte dos gestores e pela aquisição de calmantes caríssimos de laboratórios dos mesmos empresários que adoram professoras como Bárbara.

Por isso, leitor, você não leu errado o título desta crônica. São Bárbara e Pedro quem asseguram a reprodução de um sistema vil e marcado pelo abandono educacional. Contudo, são apenas reflexos de uma sociedade doente que, tal qual em Fahrenheit 451, destroem a cultura em nome de uma felicidade irreal e impositiva. Cada vez que este par de subespécies ingressa na rede, seja qual for o estado ou o município, um professor educador adoece, cai ou morre. Nesse ritmo, em poucos anos, não teremos mais educadores e o alto escalão da educação estará tomado por atores pornô e indicados de fundações telefônicas ou financeiras. Não, não acabou! Claro que há luta, caro(a) amigo(a)! Você me acompanhou neste texto até aqui e é por acreditar em almas que entendem a relação de profissionalismo que a Educação requer, mesmo sem nossa profissionalização enquanto educadores. Aposto, ainda, que você deu um riso amarelo por saber que faltam somente poucos ajustes para o extermínio do professor educador por completo. Isso, saiba caso desconheça ou ignore, pode ser feito por um Congresso eleito em nome de um autoritarismo midiático fundado em desinformação e correntes de aplicativos de celular que são os best-sellers de uma geração advinda de professores de bico ou de frustração.

Não querendo terminar negativamente esta observação cotidiana da profissão docente, fico com a alegria das crianças e dos jovens que insistem em querer algo mesmo que todos digam que não podem. Prefiro os rebeldes que desafiam os pais e escrevem seus textos e almejam a glória de serem lidos, mesmo sem prêmios Jabuti; prefiro, também, jovens que cursam as diversas artes sem se preocupar com as imposições elitizadas de pais que julgam uma tríade de formações como sendo aquelas que trarão sucesso; prefiro, evidentemente, os professores educadores que fazem o que amam e, por isso, potencializam os sonhos daqueles educandos que procuram um farol na escuridão que são suas casas, suas cidades, suas igrejas e sua sociedade. Por isso, 


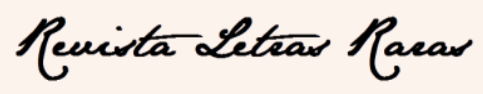

ISSN: $2317-2347$ - v. 7, n. 3 (2018)

caro(a) leitor(a), ao terminar de ler estas palavras, caso tenha filhos ou filhas, pergunte o que querem ser e incentive os nossos futuros astronautas, veterinários, professores ou qualquer outra coisa. Seja uma mola que impulsione seus filhos a serem mais do que vocês foram construídos para ser e, ao fim, teremos, novamente, uma sociedade que caminha em direção ao horizonte e amplia suas utopias. Lá, nesse futuro palpável em minha mente, verei um mar de educadores conduzindo as embarcações de esperanças e sonhos rumo à felicidade sem medicamentos. Basta querer, fazer e se posicionar contra regimes fascistas e neoliberais que nos ameaçam enquanto educadores. Saiba, então, que eu acredito em você e, seja qual for teu objetivo pessoal, será alcançado e será inspiração para outros como você e eu.

Data de recebimento: 19/10/2018

Data de aceite: 31/10/2018 